drove from Princeton to MESA's first annual conference in Chicago, continuing on to Des Moines for a visit home. With one or two exceptions, Bill never missed a MESA convention thereafter, keeping in his head a remarkable chronology of the locale of each year's meeting. He worked hard on the MESA board, the Hourani Book Award committee, and several program committees, and in 1994 was nominated for president. His fellow MESA members honored him in 2005 by re-electing him to the board for a second time. Bill was immensely pleased to learn, shortly before the onset of his final illness in August this year, that he had been chosen for MESA's 2006 Mentoring Award.

Bill was happy to become a Canadian citizen and to play a leading role in establishing Middle East studies at both Simon Fraser and across Canada. He was a key organizer, and from 1996-98 founding president of CANMES. As a valued senior statesman he recently participated in discussions reevaluating CANMES's organization and mission.

Bill worked tirelessly to convey his knowledge and empathetic understanding of Muslims and other Middle Easterners and their history to students and the public in the United States and Canada. He did not hesitate to express his dismay at disastrous turns in Middle Eastern events over the years, for many of which his native country bore heavy responsibility.

How to convey something of the sparkle of Bill's personality? He was infectiously gregarious, mixing it up in a pick-up basketball game on the outdoor court at AUC, savoring a Stella on the Nile-side veranda of Cairo's old Semiramis Hotel, chairing a panel or chatting late in the bar at innumerable MESA conventions. Inadequate as they are to capture the richness of his personality, perhaps there is comfort in old clichés. Bill was a gentleman and a scholar. The world seems emptier for his passing. Yet there is consolation in the privilege his many colleagues, golfing buddies, other friends, and several generations of students have had in knowing him.

Donald Malcolm Reid Georgia State University and University of Washington

\title{
Matthew H. Elbow (1920-2005)
}

Matthew H. Elbow passed away on 8 October 2005. He was Professor Emeritus of History at the University at Albany, State University of New York.

Born 9 August 1920, Professor Elbow earned his formal higher education entirely at Columbia University, where he received his doctorate in history in 1949. In 1947, he joined the History Department at what was then the State Normal School (it became, in 1948, the State University of New York at Albany, now the University at Albany), where he served for his entire career, until retirement in the early 1990s.

Professor Elbow's training was in French and, more broadly, European history. His main publication was French Corporative Theory 1789-1948: A Chapter in the History of Ideas (New York, 1953; reprinted by Octagon Press in 1966). In mid-career, however, and like many others of his generation, he became interested in the Middle East. Visiting professorships at the Beirut College for Women (1962-1963; the institution is now known as Lebanese-American University) and Robert College (1963-1964; the institution is now Boğaziçi University), the latter supported by a Fulbright, cemented his ties to the region and its peoples. From then on, he taught the history of the Middle East to several generations 
of undergraduates at Albany and served on various New York state committees for the study of the region.

Beyond his professorial duties, Professor Elbow had two great loves: his church (Westminster Presbyterian Church in Albany, where he was a senior member; he also received the James and Pearl Campbell Peace and Justice Award from the Capital Area Council of Churches in Albany) and the United Nations Association of America.

Professor Elbow was of a generation that valued community, teaching, students, and broad interests, rather than-as today-scholarship narrowly viewed as the activity of "independent contractors" out for fame and fortune. This is one reason for his receiving the State University of New York's Chancellor's Award for Excellence in Teaching in 1979. He brought the Middle East to thousands of students who otherwise would have been denied the opportunity. His long and rich life will be remembered by those students, and by his colleagues.

Karl K. Barbir

Siena College

\section{Deborah Gerner [1956-2006)}

Deborah J. "Misty" Gerner, a full professor of political science at Kansas University who had spent more than 25 years writing and teaching about the Middle East, passed away at her Kansas home on June 19, 2006. Her 1994 book One Land, Two Peoples: The Conflict Over Palestine (Westview Press) and her 2000 book Understanding the Contemporary Middle East (Lynne Reinner Publishers), co-authored with Jillian Schwedler, have been used in college classes throughout the United States. She was an inspiring teacher who won teaching awards for the courses she developed and taught on Middle Eastern politics, international relations, women in politics, U.S. foreign policy, and human rights. She did pioneering work (in collaboration with Phil Schrodt) in developing the Kansas Event Data System, a set of computing tools used to analyze political trends in Palestine and other conflict-wracked Middle Eastern societies. She gave considerable service to the Middle East studies and International studies communities, including service on the boards of the International Studies Association and the Palestinian American Research Center, and on the editorial boards of Arab Studies Quarterly, MERIP, International Studies Perspectives, and Intemational Studies Quarterly.

Gerner was a supportive role model for many younger women at KU (where she was inducted into the Women's Hall of Fame), and in the International studies community more broadly. Among the awards she won were the International Studies Association's Ladd Hollist Award for outstanding service, the Susan Northcutt Award for outstanding service to women scholars, and the Distinguished Alumna Award from Earlham College.

She earned her bachelor's degree from Earlham College in 1977 and her master's and doctoral degrees in Political Science from Northwestern University in 1979 and 1982 , respectively. Her professional engagements in the Middle East included numerous research trips and terms of service as a visiting professor at Birzeit University, and the American University in Cairo.

Gerner worked tirelessly for increased international understanding and for peace in the Middle East. She was a member of Oread Friends Meeting (Quakers) in Lawrence, Kansas and sought to live out the traditional Quaker testimonies of peacemaking, honesty, 